\title{
Correction to: Sterility testing using a closed system transfer device in oncology medication compounding: a novel method for testing partially used vials
}

\author{
Allan Mills ${ }^{1,2,3} \cdot$ Mary Yousef $^{1}$ \\ Published online: 3 May 2021 \\ (c) The Author(s) 2021
}

copyright holder. To view a copy of this licence, visit http:// creativecommons.org/licenses/by-nc/4.0/.

The original article has been corrected.

Open Access This article is licensed under a Creative Commons Attribution-NonCommercial 4.0 International License, which permits any non-commercial use, sharing, adaptation, distribution and reproduction in any medium or format, as long as you give appropriate credit to the original author(s) and the source, provide a link to the Creative Commons licence, and indicate if changes were made. The images or other third party material in this article are included in the article's Creative Commons licence, unless indicated otherwise in a credit line to the material. If material is not included in the article's Creative Commons licence and your intended use is not permitted by statutory regulation or exceeds the permitted use, you will need to obtain permission directly from the copyright holder. To view a copy of this licence, visit http://creativecommons.org/licenses/by-nc/4.0/.

The original article can be found online at https://doi.org/10.1007/ s40267-021-00823-4.

Allan Mills

allan.mills@thp.ca

1 Pharmacy Department, Trillium Health Partners, Mississauga, ON, Canada

2 Institute for Better Health, Trillium Health Partners, Mississauga, ON, Canada

3 Leslie Dan Faculty of Pharmacy, University of Toronto, Toronto, ON, Canada 